\title{
Use of humic preparation for increasing the effectiveness of insecticides in chickpea cultivation
}

\author{
Elena Polienko*, Artem Grinko, Vladimir Lykhman, Olga Naimi, and Yevgeny Patrikeev \\ Federal Rostov Agrarian Research Center, 346735 Rassvet, Rostovskaya oblast, Russia
}

\begin{abstract}
The article presents the results of an experiment (2016-2019) to study the influence of humic preparation on the effectiveness of insecticides of various chemical classes. Phytosanitary monitoring, pests count before and after treatment were carried out in addition to calculating the biological efficiency of insecticides; the impact on chickpea productivity and nutrition regimen was considered against the background of the chemical protection system with the inclusion of the humic preparation BIO-Don10. Harmful objects are cotton budworm (Helicovera armigera $\mathrm{Hb}$ ) and bean aphid (Aphis fabae). It was found that the pyrethroid class preparation is more effective against cotton scoop. The reduction in bean damage is $93.7 \%$. The efficiency of organophosphorus compounds does not exceed $45.0 \%$ in view of the developed stability. The preparations under study showed high efficiency against bean aphid, the decrease in aphid numbers is 93.9 and $90.9 \%$ respectively. Humic preparation did not affect this indicator, but allowed to increase the saved crop on the option with pyrethroid by $46.4-56.0 \%$, with dimethoate by $29.6-40.0 \%$.
\end{abstract}

\section{Introduction}

Currently, the Rostov oblast is in demand of leguminous crops. They occupy $8.7 \%$ in the structure of Russia's acreage, which stands for 74 thousand hectares. One of the most important tasks of the agro-industrial complex is to obtain high yields; yet in addition to providing moisture and nutritional elements, an important condition for preserving the quantity and quality of products is to protect crops from pests. Chickpeas are damaged by various harmful objects, among which there are both specialized (legume-fed only) and polyphagous species that damage many crops. The main pests of chickpeas in the Rostov region are cotton budworm (Helicovera armigera Hb.) and bean aphid (Aphis fabae). The severity of the first on chickpea is such that it is possible to lose the entire crop due to grain damage [1]. Another pest is sucking out cell sap and by that is able to cause damage and epinasty of plant shoots; as a result, there is a development delay and a productivity decrease. The most effective method of protection is an integrated protection system that involves the use of chemicals based on phytosanitary monitoring and knowledge of

\footnotetext{
* Corresponding author: polienkoe468@gmail.com
} 
biological and phenological features of harmful organisms. However, insecticide use carries a risk of suppressing plant growth and development due to toxicological load, to which legumes are extremely sensitive. Creation of stress-resistant varieties with broad agroecological adaptation is a priority direction of legumes breeding [2], but bioactive humic compounds can also be used to reduce stress and increase adaptability. By regulating the concentration of phytohormones, they help the plant to adjust quicker under conditions of toxic load [3]. At the same time, including elements in the agro-ecosystem that ensure plant growth, as well as increasing the intensity of microbiological and physico-chemical processes in soil [4].

The purpose of the study is to identify the most effective insecticide for combating cotton budworm and bean aphids from a range of chemical protection products, as well as to assess the effectiveness of combined use with humic preparation.

\section{Materials and Methods}

Research was carried out on chickpea of Donplaza variety in the Rostov oblast. The experiment was set at the station of agricultural chemistry and plant protection FRANZ in 2016 - 2019, soil - common carbonate chernozem. The number of cotton budworm on chickpea during the studies in the budding phase before the treatments varied from 4.5 to 6 $\mathrm{sp} . / \mathrm{m}^{2}$, and leguminous aphis $-17.5 \mathrm{sp}$. per 1 stem. Insecticides of various chemical classes and tank mixtures based on insecticide and humic preparation were used for pest control. The experiment scheme includes the following options: 1. Control (without pesticides); 2. Humine preparation - BIO-don10 (10 g/l of humic acids salts), $0.3 \mathrm{l} / \mathrm{ha} ; 3$. Organophosphate compounds (OPC) - Bi-58 Novyi, CE (400 g/l dimethoate) 1.0 l/ha; 4. Organophosphate compounds (OPC) + humine preparation; 5. Pyrethroids - Ampligo, MKS $(50 \mathrm{~g} / \mathrm{l} \lambda$-cyhalothrin $+100 \mathrm{~g} / 1$ chloranthaniliprol), $0.2 \mathrm{l} / \mathrm{ha}) ; 6$. Pyrethroids + humine preparation. The total experiment area $-2600 \mathrm{~m}^{2}$, plot size $144 \mathrm{~m}^{2}$, three times repetition. Before sowing, disking and cultivation to the sowing depth were carried out. Forecrop winter wheat. Fertilizers: $250 \mathrm{~kg}$ of NPK in the physical weight (16:16). Soil treatment: disking and cultivation to the sowing depth.

Pest count and efficiency assessment were carried out in accordance with [5]. The count was conducted by opening beans damaged by caterpillars on 5 plants in each repetition. Also, accounting of biological yield [6] was carried out.

\section{Results and Discussion}

As a rule, in the natural and climatic conditions of the Rostov oblast, cotton budworm develops in one generation. When the average daily temperature of air and soil reaches $+17 \ldots+19{ }^{\circ} \mathrm{C}$, the imago flight of the overwintered generation begins. It lasts about 30 days. For the next stage of development, the cotton budworm imago is intensively feeding, maintaining its activity at night and then proceeds to egg-laying. The caterpillars first feed on young upper folioles and then pass to generative plant organs. As the beans form, the caterpillars populate the entire plant. Adverse weather conditions (temperature and precipitation) as well as entomophages (predators and parasites) and viral diseases may be deterrent to pest development. However, in individual years there are outbreaks of mass reproduction at intervals of $5-8$ years. After imago flight, chickpea crops are settled by cotton budworm in 7-10 days in the budding phase and this occurs unevenly. The greatest excess of the harmfulness threshold is observed in areas adjacent to forest belts. Here caterpillars density can be more than $10 \mathrm{sp} . / \mathrm{m}^{2}$. 
Control results of fighting against such pest as cotton budworm by insecticides Bi-58 Novyi, KE (400 g/l dimethoate) and Ampligo, MKS (50 g/l $\lambda$-cyhalotrin $+100 \mathrm{~g} / 1$ chloranitriprol) are presented in figure 1. It was found that the Ampligo, MKS preparation with apllication rate of $0.2 \mathrm{l} / \mathrm{h}$ a has the highest efficiency. The reduction in bean damage by the pest compared to control amounted to $93.7 \%$. Bi-58 Novyi option $-42.1 \%$.

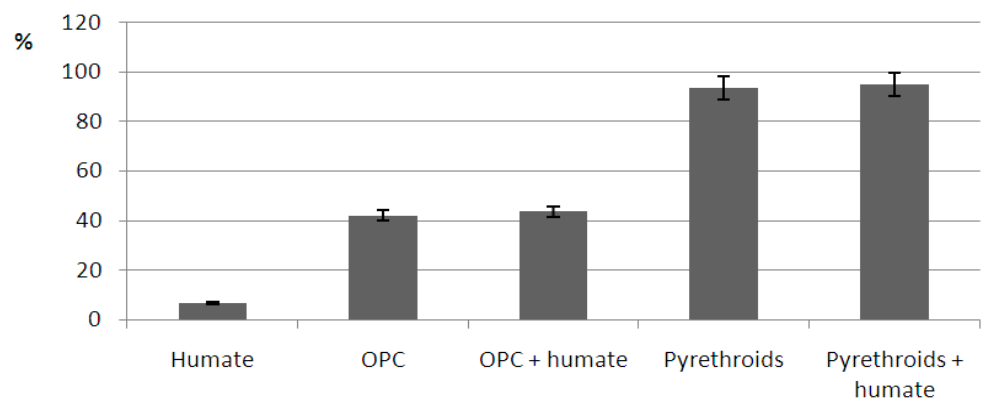

Fig. 1. The reduction in chickpea bean damage by the cotton budworm relative to control,\%.

Bi-58 Novyi is a preparation based on organophosphorus compounds. Its active substance has a strong contact and systemic insecticide action and it is moderately toxic to animals. In addition, the preparation exhibits acaricidal properties. When penetrating the plant through the root system and vegetative mass, dimetoate is spread through the plant's tissues by ascending and descending streams. It makes cell sap toxic to sucking pests. The action mechanism is in the effects on the cholinesterase enzyme, which is a transmitter of nerve impulses. Their normal transmission is disrupted, muscles convulsive activity occurs and further turns into paralysis. Regular use of this preparation causes acquired pest resistance, which causes a decrease in biological efficiency, which is why its effectiveness in the experiment is 2 times lower than the Ampligo, MKS preparation. Dimetoate has a half-life of more than 1 month, so it is applied at the beginning of vegetation.

The Ampligo preparation belongs to the pyrethroids class and is an intestinal and contact insecticide. This group of chemical compounds is highly selective and also possesses lipophily. This property allows the preparation to adhere to and hold on the surface of the leaf cuticle. At the same time, the active substance penetrates into the plant tissue gradually, and through the insect's integument - instantly, causing a rapid lesion of the nervous system, then paralysis and death. Therefore, it has such high efficiency to reduce the bean damage by cotton budworm - $93.7 \%$.

In the study of the insecticides effects on aphid numbers, pesticides based on organophosphorus compounds and pyrethroids have high biological efficiency. On the third day after treatment, the decrease in numbers relative to control with the Bi-58 Novyi, CE preparation was $100 \%$, Ampligo, MKS - 100\%. 7 days after treatment the efficiency remains high $93.0-94.1 \%$, after 14 days - $90.9-93.9 \%$ (Figure 2 ). 


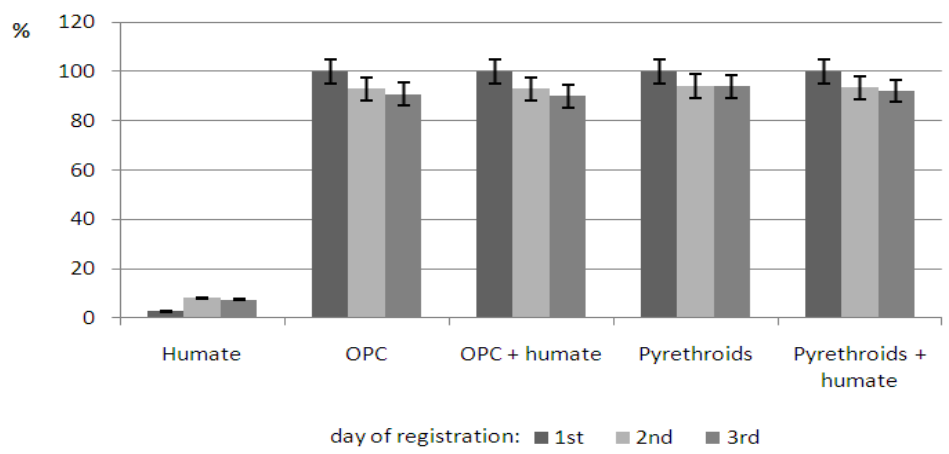

Fig. 2. Decrease in aphid numbers relative to baseline adjusted for control after chickpea treatment by accounting days.

The humic preparation is not an insecticide, so the reduction in bean damage was not affected. Bean damage by cotton budworm was at the level of control $-75.7 \%$, as well as the number of aphids - 23.8. When using a tank mixture of insecticide with a humic preparation, no reliable difference between the options was recorded. The difference in reducing the bean damage by cotton budworm with Bi-58 Novyi - 1.6\%, with Ampligo $1.3 \%$. The difference in the aphids number decrease on chickpea is $0.9 \%$ and $1.7 \%$ respectively.

In the assessment of biological yield it was established that without the use of any protection, the yield on chickpea amounted to $12.5 \mathrm{hwt} / \mathrm{ha}$. Treatment of vegetating plants with a humic growth stimulant allowed to increase yield by $1.2 \mathrm{hwt} / \mathrm{ha}$, but this value is within the experimental error. The use of Bi-58 Novyi and Ampligo insecticides allows to preserve 3.7 and $5.8 \mathrm{hwt} / \mathrm{ha}$ of leguminous crops, which is 29.6 and $46.4 \%$ respectively. However, phenological observations observed phytotoxic effect of Bi-58 Novyi on cultivated plants, which is a specific reaction to organophosphorus compounds: slight stem epinasty, light and yellowish color of the plant itself. Plants were not visually different from untreated ones in options with joint application with BIO-don10. The stress reduction allowed for an increase in relation to control on the option with the Bi-58 Novyi $5.0 \mathrm{hwt} / \mathrm{ha}$, with Ampligo $7.0 \mathrm{hwt} / \mathrm{ha}$. It corresponds to 40.0 and $56.0 \%$. Thus, the effectiveness of insecticides was improved by 10.4 and $9.6 \%$ respectively (Figure 3 ).

The stress of insecticide use affects not only the growth and development of plants, but also the reduction of their ability to absorb nutritional elements. Dry conditions (HTR (hydrothermal precipitation-evaporation ratio $=0.81$ ) contribute to the fact that moving elements are not washed down the soil profile, on the contrary, they accumulate in the arable layer. At the time of sowing, the soil provision of mobile nitrogen forms with a range of $17.2-18.7 \mathrm{mg} / \mathrm{kg}$ was estimated as average, while the content of nitrate forms was very low - only $2.8-4.5 \mathrm{mg} / \mathrm{kg}$. After sowing, a complex fertilizer of ammophos (16:16:16) was introduced before the shoots appearance. 


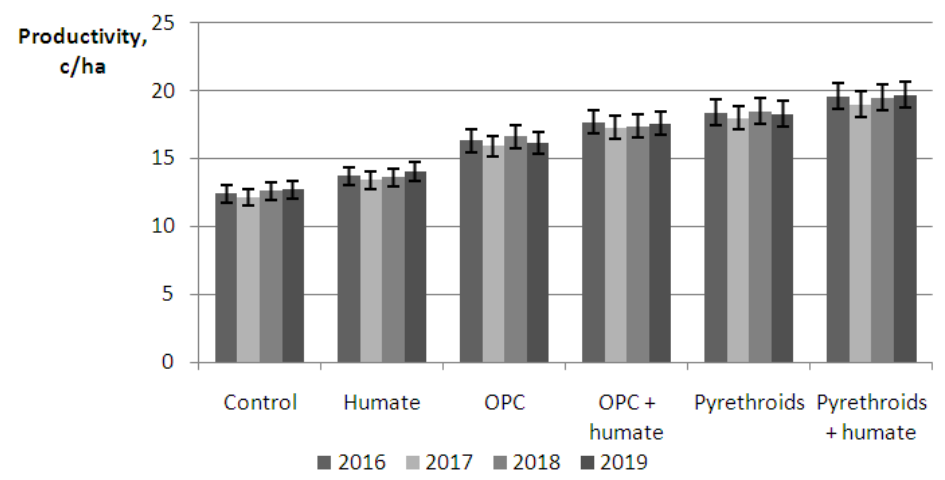

Fig. 3. The yield of chickpeas when using insecticides of different class with humine preparation.

Two weeks after the vegetating plants treatment, there is an increase on the experimental options in nitrate nitrogen form to $13.6-16.8 \mathrm{mg} / \mathrm{kg}$, which is normal due to the application of complex fertilizer. But at the same time, this increase is not as strongly expressed with the use of a humic preparation, the content of nitrate forms 11.1-13.0 $\mathrm{mg} / \mathrm{kg}$. This is due to the physiological activity of humine compounds. Nitrificationproduced nitrate ions are more intensely consumed by the plant to cope with stress from chemicals. And against the background of the humic growth stimulant, there is a reduced absorption capacity observed: on the option with BIO-Don10, the $\mathrm{N}-\mathrm{NO}_{3}$ content is 11.1 $\mathrm{mg} / \mathrm{kg}$, and on options with insecticides $-13.0 \mathrm{mg} / \mathrm{kg}$ (table 1 ).

Table 1. Dynamics of nutritional elements in soil during chickpea cultivation using insecticides of different class and humic preparation, $\mathrm{mg} / \mathrm{kg}$.

\begin{tabular}{|c|c|c|c|c|c|c|c|c|}
\hline \multirow{2}{*}{ Option } & \multicolumn{4}{|c|}{ before processing } & \multicolumn{4}{|c|}{ after processing } \\
\hline & $\mathrm{NO}_{3}$ & $\mathrm{NH}_{4}$ & $\mathrm{P}_{2} \mathrm{O}_{5}$ & $\mathrm{~K}_{2} \mathrm{O}$ & $\mathrm{NO}_{3}$ & $\mathrm{NH}_{4}$ & $\mathrm{P}_{2} \mathrm{O}_{5}$ & $\mathrm{~K}_{2} \mathrm{O}$ \\
\hline Control & $\begin{array}{c}2,8 \pm 0 \\
1 \\
\end{array}$ & $\begin{array}{c}13,6 \pm 0 \\
7 \\
\end{array}$ & $9,9 \pm 0,5$ & $\begin{array}{c}365,7 \pm 18 \\
, 3 \\
\end{array}$ & $\begin{array}{c}13,6 \pm 0 \\
7 \\
\end{array}$ & $\begin{array}{c}15,2 \pm 0 \\
8 \\
\end{array}$ & $\begin{array}{c}22,1 \pm 1 \\
1\end{array}$ & $\begin{array}{c}453,4 \pm 22 \\
7 \\
\end{array}$ \\
\hline Humate & $\begin{array}{c}3,2 \pm 0 \\
2 \\
\end{array}$ & $\begin{array}{c}14,6 \pm 0 \\
7 \\
\end{array}$ & $\begin{array}{c}11,4 \pm 0, \\
6 \\
\end{array}$ & $\begin{array}{c}368,9 \pm 18 \\
, 4 \\
\end{array}$ & $\begin{array}{c}11,1 \pm 0 \\
6\end{array}$ & $\begin{array}{c}17,0 \pm 0 \\
9 \\
\end{array}$ & $\begin{array}{c}11,1 \pm 0 \\
6 \\
\end{array}$ & $\begin{array}{c}439,6 \pm 22 \\
0\end{array}$ \\
\hline OPC & $\begin{array}{c}4,4 \pm 0 \\
2 \\
\end{array}$ & $\begin{array}{c}14,1 \pm 0 \\
7 \\
\end{array}$ & $\begin{array}{c}10,6 \pm 0, \\
5 \\
\end{array}$ & $\begin{array}{c}362,4 \pm 18 \\
, 1 \\
\end{array}$ & $\begin{array}{c}14,8 \pm 0 \\
7 \\
\end{array}$ & $\begin{array}{c}18,0 \pm 0 \\
7 \\
\end{array}$ & $\begin{array}{c}22,8 \pm 1 \\
0 \\
\end{array}$ & $\begin{array}{c}395,9 \pm 19 \\
8 \\
\end{array}$ \\
\hline $\begin{array}{l}\text { OPC + } \\
\text { humate }\end{array}$ & $\begin{array}{c}3,3 \pm 0 \\
2 \\
\end{array}$ & $\begin{array}{c}14,3 \pm 0 \\
7 \\
\end{array}$ & $\begin{array}{c}11,6 \pm 0, \\
6 \\
\end{array}$ & $\begin{array}{c}375,4 \pm 18 \\
, 8 \\
\end{array}$ & $\begin{array}{c}12,9 \pm 0 \\
6 \\
\end{array}$ & $\begin{array}{c}17,2 \pm 0 \\
9\end{array}$ & $\begin{array}{c}25,9 \pm 1 \\
3 \\
\end{array}$ & $\begin{array}{c}402,3 \pm 20 \\
1\end{array}$ \\
\hline $\begin{array}{l}\text { Pyrethroid } \\
\text { s }\end{array}$ & $\begin{array}{c}4,5 \pm 0 \\
2 \\
\end{array}$ & $\begin{array}{c}16,6 \pm 0 \\
8 \\
\end{array}$ & $\begin{array}{c}10,6 \pm 0, \\
5 \\
\end{array}$ & $\begin{array}{c}381,9 \pm 19 \\
, 1 \\
\end{array}$ & $\begin{array}{c}16,8 \pm 0 \\
8 \\
\end{array}$ & $\begin{array}{c}19,9 \pm 1 \\
0\end{array}$ & $\begin{array}{c}26,8 \pm 1, \\
3 \\
\end{array}$ & $\begin{array}{c}400,7 \pm 20 \\
0 \\
\end{array}$ \\
\hline $\begin{array}{l}\text { Pyrethroid } \\
s+\text { humate }\end{array}$ & $\begin{array}{c}3,7 \pm 0 \\
2\end{array}$ & $\begin{array}{c}14,6 \pm 0 \\
7\end{array}$ & $9,7 \pm 0,5$ & $\begin{array}{c}343,0 \pm 17 \\
, 2\end{array}$ & $\begin{array}{c}13,0 \pm 0 \\
7\end{array}$ & $\begin{array}{c}18,1 \pm 0 \\
9\end{array}$ & $\begin{array}{c}27,8 \pm 1 \\
4\end{array}$ & $\begin{array}{c}399,1 \pm 20 \\
0\end{array}$ \\
\hline
\end{tabular}

The ammonium nitrogen content in soil after treatment on all options with the use of humate is also somewhat reduced. If the ammonium form reserve was $13.6-16.6 \mathrm{mg} / \mathrm{kg}$ before fertilizer application, it increased to $20 \mathrm{mg} / \mathrm{ha}$ after application. However, it was slightly less on options with humic preparation $-17.0 \mathrm{mg} / \mathrm{ha}$.

Thus, mineral fertilizer containing both ammonium and nitrate forms contributes to an increase in the number of mobile forms of nitrogen to $36 \mathrm{mg} / \mathrm{ha}$, which is assessed as "good". These options also show a decrease in nitrate content in humate treatment by $2-4$ $\mathrm{mg} / \mathrm{kg}$. As for ammonium ions, this form is much better absorbed by the plant to build the protein as less ATP is spent to transfer into the amide form, so two weeks after the treatment the ammonium nitrogen content is returned to the initial value of $14-16 \mathrm{mg} / \mathrm{kg}$. However, with the use of highly toxic insecticides the content of this form of nitrogen 
remains elevated, probably the plant is unable to develop normally and fully assimilate nutritional elements in stress conditions.

Soil reserve of mobile forms of phosphorus is characterized as low. After fertilization, the content of mobile phosphates increases to $18.1 \mathrm{mg} / \mathrm{kg}$. On the control option, the content of mobile phosphates is $22.1 \mathrm{mg} / \mathrm{kg}$, while remaining high on options with insecticides - up to $27.8 \mathrm{mg} / \mathrm{kg}$, but the use of humic preparation causes a decrease to $11.1 \mathrm{mg} / \mathrm{kg}$. The reasons for this phenomenon have been described by us earlier [7, 8].

The distribution of exchange potassium in the soil is uniform and its content is assessed as elevated. When the mineral fertilizer is applied on the control option, the value of this indicator increases to $400 \mathrm{mg} / \mathrm{kg}$ and is assessed as high. However, the option using humic drug also shows a tendency to reduce potassium exchange by $5-10 \mathrm{mg} / \mathrm{kg}$.

\section{Conclusion}

During the experiment it was found that the use of insecticides in chickpea cultivation allows to preserve up to $46.0 \%$ of the crop. The use of humic preparation together with highly toxic insecticides allows to increase their effectiveness due to its adaptive action on plants by $9.0-10.0 \%$. The increase to chickpea yield with joint use of chemical protection and humic preparation is $56 \%$ to control.

The use of humic preparation on chickpea has a negative dynamics on the content of nutrients. This is caused by the fact that humic compounds have physiological activity and help the plant cope with toxic load under conditions of pesticide stress enhanced by dry weather, resulting in more complete consumption of nutritional elements from the soil.

\section{References}

1. V.N. Cherkashin, A.N. Malykhina, G.V.Cherkashin. Agriculture, 5 (2014)

2. V.I. Zotikov, N.V. Gryadunova et al., Agriculture, 4, 6-8 (2014)

3. F.M. Shakirova, Non-specific plant resistance to stress factors and its regulation (Ufa: Gilem, 2001)

4. Y.D. Van Mansvelt, S.K. Temirbekova, Agricultural biology, 52(3), 478-486 (2017)

5. Methodical instructions for registration tests: insecticides, acaricides, molluscicides and rodenticides in agriculture $(\mathrm{SPb}, 2013)$

6. B.A. Dospekhov, Field experiment technique (M.: Agropromizdat, 1985)

7. E.A. Polienko, O.S. Bezuglova, A.V. Gorovtsov et al., Achievements of science and technology of the agro-industrial complex, 30(2), 24-28 (2016)

8. O.S. Bezuglova, A.V. Gorovtsov, E.A. Polienko et al., J. Soils \& Sediments, 19(6), $2665-2675$ (2019) 